\title{
Identifying indicators that can play a meaningful role in promoting creativity in SMEs - a South African study
}

\author{
G.J.P. Maas, T.J. de Coning \& E.vd M. Smit \\ Private Bag X6011. Port Elizabeth 6000. South Africi \\ Gideon@ml petech.ac.za
}

Received May 1999

\begin{abstract}
This study focused on identifying indicators that can play a meaningful role in promoting creativity in South African small and medium-sized enterprises (SMEs). Seven indicators of creativity for SME owners and four for the SME: organisation were identified. The present profile of South African SME owners does not correspond with these indicators. providing some clues to the lack of creativity in the SME sector.
\end{abstract}

* Prof G.J.P. Maas is heading the International Chair in Entrepreneurship at the Port Elizabeth Technikon. Rhodes University and University of Limerick (Ireland); prof T.J. De Coning and prof E. vd M. Smit are professors at the University of Stellenbosch

\section{Introduction}

The advantages of developing small and medium-sized enterprises (SMEs) are recognised by various authors such as Clay \& Creigh-Tyte (1994: 2) who refer to the job creation role of SMEs that has outstripped that of larger firms: Claessens (1982: 1) who states that SMEs have a better chance of survival in a fast-changing environment and therefore create a stable environment; Visagie (1996: 35) who argues that SMEs are important contributors to the community in the form of social services, education and provision of employment; and Thomas (1995: 13) who states that SMEs have the potential to stimulate entrepreneurship, activate competition in the economy and are supportive in adapting to the challenges of even greater international competition. The above advantages are accepted by the South African Govemment, which states that the small business sector is seen as an important force for generating employment and more equitable income distribution, for activating competition, exploiting niche markets (both domestically and internationally), enhancing productivity and technical change, and through all of this, stimulating economic development (White Paper of the Department of Trade and Industry, 1995: 10). However, the national and international environments are characterised by fast changes that offer unique challenges and threats to SMEs. One way of ensuring that SMEs in South Africa not only survive in such an environment, but also contribute to the country's economic growth and development as set out in the White Paper, is by stimulating creativity in this sector.

\section{Overview of literature}

This study focused on two complex study fields, namely creativity and SMEs. According to Gundry, Kickul \& Prather (1994: 22) creativity lends itself to various interpretations. Hallman (in Groenewald, 1970: 8) agrees with them and comments on this as follows: for example, the philosopher tends to discover the grounds for creative production among the final powers operating in the universe; the psychologist, among the dynamics of personality functions; the scientist. among the self-regulating forces of protoplasm or of manter the artist and writers, among the products which they create the engineers and politicians. among the externally delined needs which they confront; the businessmen and managerial officers, among the interpersonal relations of their organisations. On the issue of SMEs. Claessens (1982: 2) remarks that a uniform SME theory does not exist and that it is actually in a development phase. In order to deal with this complexity, relevant literature was studied and a conceptual model was developed and used as basis for the primary research conducted. A brief overview of the literature will he discussed in the following paragraphs. followed by a discussion of the primary research conducted

\section{Creativity}

The main theoretical approaches to creativity can be classified into various schools, namely the psycho-analytical. perceptual, behaviourist, cognitive-rational, personality. biophysiological, gifted/genius and humanist schools. Each of these analyses and questions issues from their own perspectives (Smuts, 1992: 45). Due to this, different definitions for creativity exist, such as that by Guilford (1986: 1), who defines creativity as the characteristic that distinguishes something from other things, which can then be classified as creativity, such as new designs. Baron (1969: 10) defines creativity as the creation of something new. Wesi \& Farr (1990: 10) define creativity as the creation of something new as a result of the individual's own competence or due to the interaction between the individual and his environment. and Kuratko \& Hodgetts (1995: 66) define creativity as the generation of ideas that result in the improved effectiveness of a system.

According to Welsh (1975: 5), Henry (1991:5) and Rhodes (in Joubert, 1993: 42), four common elements can be identified in most definitions. namely the characteristics of the creative person, creative processes, an environment that can promote creativity, and manifestations of creativity. These four elements are discussed below 


\section{Characteristics of creative people}

The characteristics of creative people have been identified by various authors. In this regard Charnes \& Cooper (1984: 188) identify high energy levels, a high level of intuition, self confidence, broad interest and a drive for unique experiences. Drucker (1986: 151) adds that a creative person is more focused on contents of assignments and not the organisation itself, the creative person is more focused on action and does not love routine, and he is very competitive. Sternberg (1988: 68) supports the above views and further indicates that a creative person is willing to accept risks if a supportive climate exists in that organisation. Amabile (in Henry, 1991: 6) concludes that creative people possess three types of skills, namely domain-relevant skills (e.g. specific knowledge regarding a discipline), creative-relevant skills (e.g. thinking skills), and task-motivation (e.g. to be motivated to be creative). Various other authors can be cited, but the most important finding regarding the characteristics of a creative person is that everybody possesses the potential to be creative, and that characteristics that enhance creativity are present to a greater or lesser extent in every individual. The research of the above authors also indicates that creativity can be enhanced by means of planned actions, for example by the teaching of thinking skills.

\section{Creative process}

The creative process refers to the different phases an individual goes through to reach his goal. In this respect various authors identify different phases. Wallas (in Lytton, 1971: 10-13) and Lessem (in Henry, 1991: 264) identify four phases, namely preparation, incubation, insight and testing. Evans \& Russel (1990: 48) identify five phases, namely preparation, frustration, incubation, insight and testing. After evaluation of the different processes, it was concluded that all the processes have four common phases, namely preparation, incubation, illumination and testing. During the first phase, preparation, information is obtained, skills are developed, and alternative ideas are generated to solve a problem or to exploit an opportunity. When answers cannot be found by means of traditional and analytical methods, the person can become frustrated and may try to avoid the problem. However, the subconscious mind keeps on working on the problem in order to find a solution. The latter is called the incubation phase. During the illumination phase, the individual finds a solution. Dutton \& Kransz (1985: 2-9) indicate that the AHA reaction (Eureka principle) is a typical reaction during this phase. However, this creative reaction is not possible without creative action - the preparation phase. In the final phase the feasibility of the solution is tested.

\section{Environment}

The environment may include a person's personal environment, the business environment and the educational environment. Since this study was focused on SMEs, the business environment was used as point of departure. West \& Farr (1990: 10) and Joubert (1993: 81) indicate that the environment plays a crucial role in enhancing creativity. The interaction between the individual and his environment is essential for him to be creative. Couger, Higgins \& McIntyre (1993: 379) furthermore indicate that there is a positive correlation between the work environment and the enhance. ment of creativity. They also highlighted that an environment that promotes creativity is not an automatic process, but mus be created actively by the owner. According to Gundry Kickul \& Prather (1994: 34), such an environment is characterised inter alia by trust, openness, the existence of humour and the debating of issues. Engelbrecht (1993: 40) adds to this list the necessity of open communication systems, honesty and objectivity regarding own creations, enough resources and freedom to achieve results.

\section{Manifestations of creativity}

When creativity is encouraged in an SMF, it can be expected to result in final products and services (Couger et al., 1993: 379). However, the question is which products and services can be regarded as creative? Various authors try to define manifestations of creativity, for instance Guilford (1986: 1) refers to new inventions, Baron (1969: 10) to something new, and Kreitner (1989: 245) to new configurations. However, nobody has provided a list of criteria according to which a product or service can be classified as a creative outcome. Should such a list exist, it is generally accepted that such an evaluation is highly subjective, because it is judged according to the perceptions of different individuals.

Regarding the problem of subjectivity, Amabile (in Smuts, 1986: 133) suggests that the subjective identification of a creative product and service must be accepted. She further states that a product or service is creative to the extend that appropriate observers independently agree it is creative. Appropriate observers are those familiar with the domain in which the product was created or the response articulated. To find a panel of appropriate judges can be tiresome and an impractical task in the context of this study. It was therefore decided to approach the identification of creative products and services from the angle of respondents. It was accepted that they can be the best judge whether their products and services can be regarded as creative or not because of the assumption that they are appropriate observers in a specific domain. The subjective nature of such an identification system is therefore accepted.

The identification of creative outcomes is further complicated by potentially different levels of creativity. Amabile \& Ghiselin (in Smuts, 1986: 124) suggest that products and services can be classified according to a dichotomous scalecreative or not creative. Products and services are therefore classified as either creative or not creative. Where respondents in this study mentioned that they could not identify any creative outcomes in their SMEs, the answer was classified as not creative. If they could mention a product or service, the answer was interpreted in a positive way. Therefore it was arbitrary decided to use this method on an explorative way.

\section{Summary}

The above four elements were used to formulate the following operational definition for the purposes of this study:

Creativity is the accomplishment of new, useful developments as a result of the interaction between an individual and his/her environment. 
The accomplishment refers to the different processes that can be used; new to activities that can be regarded as new for a specific SME in the context of South Africa; useful to manifestations that add value to the activities of an SME; individual to the creative individual; and, environment to the internal and external environment with which the individual continuously interacts

\section{SMES}

D'Amboise \& Muldoney (1984: 2) argue that there are three important interactive perspectives that can help us to form a better understanding of SMEs. These three perspectives are the task environment, organisational issues and management characteristics. This approach is supported by Welsh (1975: 5) and Henry (199l: 5). However, the approach by D'Amboise \& Muldoney (1984) addresses all issues relating to SMEs and was therefore used as basis for further investigation. An overview of the most important findings is discussed below.

\section{Task environment}

The task environment refers to the immediate environment of an SME, consisting inter alia out of competitors, suppliers and customers. According to Coetzee, Havenga \& Visagie (1993: 1), no SME can act in isolation and therefore needs to interact dynamically with its environment. This is supported by Sexton \& Van Anken (1985: 8), who state that an SME that reacts dynamically to environmental changes will show better results.

In order to react dynamically to environmental changes, SME owners need information. This is supported by Evans \& Russel (1990: 3), who also indicate that the rate of change will probably accelerate due to the availability of reliable information. In this regard Hartman, Tower \& Sebora (1994: 37) indicate that SME owners get information from a wide variety of sources. The most frequently used sources are the person himself, family members and sales representatives. A very important support mechanism for SME owners are their network system, which enable them to generate reliable and timely information (Johannison, 1992: 102 and Longenecker, Moore \& Petty, 1994: 432). These networks will, however, be different for different situations (Churchill \& Lewis, 1983: 34), for instance in a survival phase an SME owner will probably focus more on questions such as cash generation and break-even points and therefore needs people who can help him with that.

\section{Organisational behaviour}

Organisational behaviour focuses primarily on structures and processes in SMEs. Morris (1993: 2) draws a distinction between entrepreneurial and small business organisations. He argues that the entrepreneurial organisation is more creative than the small business organisation due to the futuristic and opportunity-driven approaches of the former. However, the focus remains on how SMEs are organised to achieve their goals in a dynamic environment. In this regard Sheitogan \& Cote (in D'Amboise \& Muldoney, 1984: 30-31) argue that structures must be flexible and that they will change according to environmental changes. Churchill \& Lewis (1983: 50) support this view and add that the phase of development will also have a critical impact on structures, for instance a newly established SME will be structured differently from a growing SME. Schölhammer \& Kuriloff (1979: 180-181) finally indicate that structures in SMEs are different from those of large organisations. Therefore an SME cannot be regarded as a small large organisation.

\section{Characteristics}

Carland, Hay \& Carland (in D'Amboise \& Muldoney, 1984: 11) draw the following distinction between entrepreneurs and small business owners.

An entrepreneur is an individual who establishes and manages a business for the principal purpose of profit and growth. The entrepreneur is characterised mainly by innovative behavior and will employ strategic management practices in the business. A small business owner is an individual who establishes and manages a business for the principal purpose of furthering personal goals. The business must be the primary source of income and will consume the majority of the owner's time and resources. The owner perceives the business as an extension of his or her personality, intricately bound with family needs and desires.

Pleitner (1984: 4-6) and Smith \& Miner (1983: 326) support this view. Pleitner (1984: 4-6) further states that the majority of owner-managers tend not to be entrepreneurs. From the above it can be deduced that entrepreneurial SME owners will be more inclined towards creativity.

Various authors have done research on the typical characteristics of an entrepreneur. for instance Bhide (1994: 160), Amit, Glosten \& Muller (1993: 817). Banfe (1991: 7) and Andrén \& Uudelepp (1993: 221-222). The list of characteristics includes inter alia creativity. technical know-how, perseverance and internal locus of control. De Coning (1988: 5659), however, focused on the South African environment and identified the following characteristics of an entrepreneur that support the work of above researchers, namely calculated risk taker, internal locus of control, holistic approach, knowledge and experience regarding technical and management skills, value system and motivation, which focus on growth and development through the creative exploitation of opportunities. These characteristics also support the characteristics of a creative person.

\section{Conceptual model}

All the elements obtained from the literature studies on creativity and SMEs were integrated in an SME profile consisting of the characteristics of SME owners (Part A, Annexure A), SME behavioural practices (Part B, Annexure A), and manifestations of creativity (Part C, Annexure A).

The integrated SME profile was converted into a conceptual model (see Figure 1), which served as a basis for an empirical investigation. This model contains three important propositions. Firstly, it proposes that SME owners who are creative will produce creative outcomes. Secondly, the structures and processes of SMEs can stimulate creativity, which will result in manifestations of creativity. Lastly, it proposes that manifestations of creativity will be probable if the first two components function optimally 


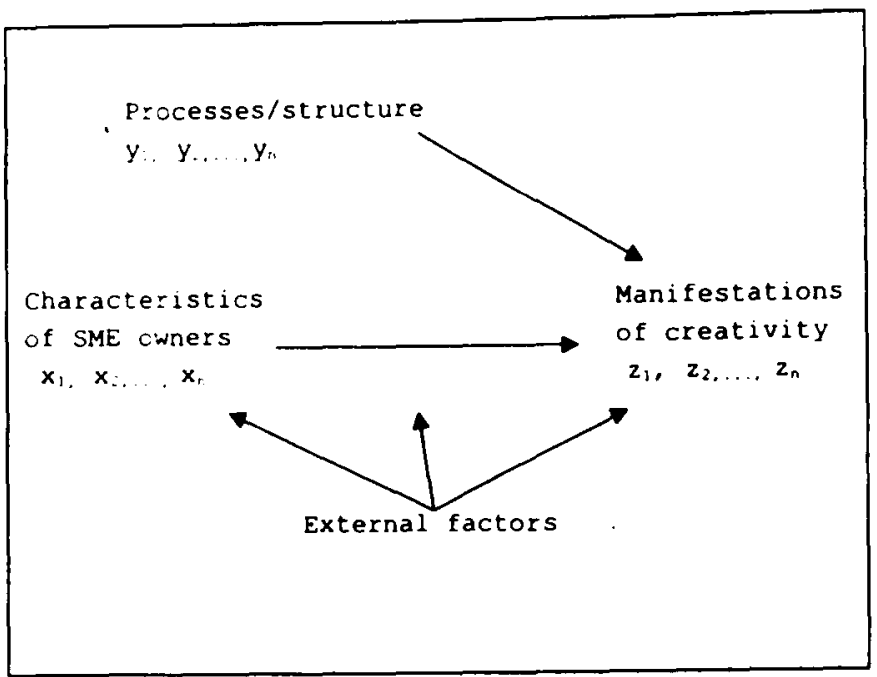

Figure 1 Conceptual model (Maas, 1996: 82)

The detailed characteristics of SME owners ( $x^{\prime}$ to $\left.x^{n}\right)$ are outlined in Part A, Annexure A; processes and structures of SMEs $\left(y^{l}\right.$ to $\left.y^{n}\right)$ in Part B, Annexure $A$; and manifestations of creativity $\left(z^{\prime}\right.$ to $\left.z^{n}\right)$ in Part $C$, Annexure $A$.

\section{Method}

To ensure a large extent of homogeneity among SMEs and the direct involvement of the SME owner in this study, it was decided to define SMEs as follows for the purposes of this study: all SMEs that were geographically situated within the borders of South Africa, that were not part of a larger enterprise, that did not have more than 100 employees, and that were in the manufacturing, commercial and service sectors (major divisions 3 and 6 of the Standard Industrial Classification of all economic activities). It was decided in advance that about 300 responses were needed for the purpose of higher-order statistical procedures, because that way the danger of empty cells that might have a negative influence on calculations would be eliminated. It was also assumed that a $10 \%$ response on the questionnaire method would be possible, and therefore a randomly selected list of 3659 addresses were obtained from the Bureau of Market Research of the University of South A frica. More than 3000 addresses were requested to allow for-organisations that had gone bankrupt and organisations that did not fit the criteria. This list was inspected and addresses that did not fit the criteria were removed, as were those of organisations that were known not to exist anymore. In this way the addresses were reduced to 3310 .

Due to various reasons (e.g. SME owners' limited time and the large sample) it was decided to use the questionnaire method to collect data. Due to the qualitative nature of the data, nominal and ordinal scales were used (see Annexure A).

After the questionnaire had been completed, it was tested by asking selected people with broad experience of the SME sector to complete it and to discuss it in detail afterwards. In the actual study, a total of 401 questionnaires $(12.10 \%$ of the random sample of 3310), were returned. Telephone enquiries confirmed that it was neither the study nor the subject of the questionnaire that caused the relatively low response. Of the 401 questionnaires that had been returned, $342(10.30 \%)$ could be used for this study. The remaining 59 could not be used due to insufficient intormation (36), too many employ. ees (10), and organisations that did not exist (13).

In order to determine whether the responses were indeed representative of the regional characteristics of the population, a Chi-square test had been carried out. The total number of responses was classified according to postal codes to provide an indication of the distribution of responses in South Africa. The critical value at a $0.50 \%$ confidence level is 23.59 , which was more than the calculated value of 23.18 (Maas, 1996: 117). The null hypothesis of coinciding distributions in the universum and sample was therefore not re jected.

The aim of this study was to identify possible indicators of creative manifestations in SMEs. The latter is the dependant variable in the context of this study and because of its categorical nature, standard regression analysis could not be used (Cooper \& Weekes, 1983: 375-377). Cooper \& Weekes (1983: 377 ) are also of the opinion that a logistical model is better suited for situations where the dependant variable is a categorical variable. Berenson, Levine \& Goldstein (1983: $477-478$ ) also suggest that the analysis of contingency tables can best be performed by means of log-linear models. Due to the above it was decided to use a stepwise logistical regression for binary dependant variables (creativity).

Due to the exploratory nature of this study it was decided to use single and compound variables, the reason being that single variables lend themselves to the investigation of finer associations in the data, and compound variables will eliminate a potential problem of too many empty cells.

These single and compound variables were used in five different sets of measurements. In Phase 1 only single variables regarding SME owners' characteristics were used (see Category A in Annexure A), and in Phase 2 only single variables regarding SMEs' characteristics were used (see Category B in Annexure A). In Phase 3 only the indicators that had been identified in Phases 1 and 2 were used to investigate possible finer associations in the data. These indicators were used again in Phase 4 in a combination with compound variables. Lastly, only compound variables were used in Phase 5. These different phases covered all possible combinations of single and compound variables, thus underlining the explorative nature of this study.

\section{Results}

The results of the exploratory method that was applied to identify indicators are represented in Table 1.

In Phase 1, financial management training, internal locus of control and marketing management training, which was identified as meaningful only in step 5 , were identified as possible indicators. In step 3 of this specific analysis, careful maintenance of the quality of products/services was identified as an indicator. In step 4, however, it was removed from the model because the p-value' was 0.34 , which was larger than the stated assumed p-value of 0.10 . In Phase 2, analysis of the environment of an SME and idea-generating sessions were identified as indicators. In Phase 3 , the three meaningful indicators of SME owners (results of Phase 1) and the two characteristics of the SME enterprises (results of Phase 2) were used as variables in a subsequent phase of stepwise 
Table 1 Indicators identified by means of stepwise logistic regression

\begin{tabular}{|c|c|c|c|c|c|c|c|c|c|}
\hline $\begin{array}{l}\text { Single owner's } \\
\text { characteristics } \\
\text { (phase 1) }\end{array}$ & & $\begin{array}{l}\text { Single enterprise } \\
\text { characteristics } \\
\text { (phase 2) }\end{array}$ & & $\begin{array}{l}\text { Selected single } \\
\text { indicators } \\
\text { (phase 3) } \\
\end{array}$ & & $\begin{array}{l}\text { Single and combined } \\
\text { variables } \\
\text { (phase } 4 \text { ) }\end{array}$ & & $\begin{array}{l}\text { (ombined variables } \\
\text { (pluase 5) }\end{array}$ & \\
\hline Step indicator & $\mathrm{p}$-value & Step indicator & p-value & Step indicator & $p$-value & Step indicator & p-value & Step indicators & $p$-value \\
\hline $\begin{array}{l}\text { I Financial management } \\
\text { information }\end{array}$ & 0.000 & 1 Analyses & 0.000 & I Analyses & 0.000 & I Creative systems & 0000 & I Creative systems & 0000 \\
\hline 2 Locus of control & 0.037 & $\begin{array}{l}2 \text { Idea-generating } \\
\text { sessions }\end{array}$ & 0.003 & $\begin{array}{l}2 \text { Idea-generating } \\
\text { sessions }\end{array}$ & 0.003 & $\begin{array}{l}2 \text { Financial manage- } \\
\text { ment training }\end{array}$ & 0.009 & 2 Locus of control & 0.018 \\
\hline \multirow[t]{3}{*}{$\begin{array}{l}5 \text { Marketing management } \\
\text { training }\end{array}$} & 0.093 & & & $\begin{array}{l}3 \text { Financial man- } \\
\text { agement training }\end{array}$ & 0.010 & 3 Locus of control & 0.029 & $\begin{array}{l}3 \text { Training in four } \\
\text { areas }\end{array}$ & 0023 \\
\hline & & & & $\begin{array}{l}4 \text { Locus of } \\
\text { control }\end{array}$ & 0.031 & $\begin{array}{l}4 \text { Value system and } \\
\text { motivation }\end{array}$ & 0.098 & $\begin{array}{l}4 \text { Value system and } \\
\text { motivation }\end{array}$ & 0.035 \\
\hline & & & & & & 5 Business structures & 0.063 & $\begin{array}{l}5 \text { Business } \\
\text { structures }\end{array}$ & 0.033 \\
\hline
\end{tabular}

logistic regression. Of the five variables, only marketing management training was not identified as a meaningful indicator in this phase.

The variables that were identified as meaningful indicators in Phase 4 were financial management training, locus of control, creative systems, value system and motivation and business structures. Analyses and idea-generating sessions that had been identified as indicators in Phase 3, were represented by the compound variable creative systems in Phase 4 . In Phase 5, only training was identified as a meaningful new indicator.

A final result obtained by means of stepwise logistical regression was the forecast probability that the indicators could bring about an improvement in the clarification of manifestations of creativity (see Table 2). The various phases agreed with those of Table 1.

Table 2 indicates that the probability of manifestations of creativity increases to the degree that the SME have an internal locus of control. This tendency was observed in all the phases where locus of control was identified as an indicator. In the case of business structures, the probability of manifestation of creativity increased to the extent that more entrepreneurial structures were used. The same tendency was observed regarding creative systems, where the probability of manifestation of creativity increased to the extent that more creative systems were used.

In the case of value systems and motivation of an SME owner, the probability of manifestations of creativity increased to the extent that the value system and motivation were those of an entrepreneur. However, this probability later decreased. The statistics did not contain an explanation for the initial increase and the subsequent decrease.

In the case of training, the probability of creative manifestations increased to the extent that the SME owner received preliminary training in four functional areas. This tendency was supported by the same trend in the probability observed in financial management training and marketing management training. Lastly, a high probability was indicated in the case of analysis and idea-generating sessions.

The various indicators identified in this study were finally compared with descriptive statistics to provide an indication whether SMEs were creative (see Table 3). If more than $50 \%$ of the responses indicated an unfavorable situation (e.g. more than $50 \%$ of the responses indicated that they had no financial management training before starting with business), it was regarded as a deficiency. From Table 3 it is clear that for SME owners, deficiencies existed for most of the indicators. In the case of SME characteristics, however, three of the four indicators showed no deficiency.

\section{Conclusion}

This study made four major contributions towards the study field of SMEs. Firstly, it focused on the role of creativity in SMEs. The role of creativity was argued from a business economics perspective because it was assumed that creativity will have no meaning for SMEs unless it contributes towards the growth and development of an SME

Secondly, this study identified various indicators that can play a meaningful role in the promotion of creativity in SMEs. It can help focus attention on planned interventions that do have a probability of improving the creative potential of SMEs. Since the indicators identified are skills as well as behavioral-related, a balanced approach in the promotion of creativity can be achieved. It is assumed that if creative potential of SMEs can be enhanced, this will eventually lead to a better support of national goals in South Africa.

Thirdly, this study contributed to the debate in South Africa as to whether SMEs locally can actually contribute to the growth and development of the economy. If it is excepted that creativity is a very important aspect of entrepreneurship and that entrepreneurship in turn is a very important aspect in stimulating the growth and development of an economy, then some answers can be found by comparing the indicators with actual data (descriptive statistics). Although the way deficiencies between indicators and descriptive statistics were determined can be regarded as subjective, it still provides a very important overview of where deficiencies exist. It is very important to note that most of the deficiencies exist in the characteristics of SME owners, and not those of the enterprise. This is significant, especially when it is compared with descriptive statistics where $41.23 \%$ of respondents indicated that there was no creativity in their business.

The above leads to the final conclusion, namely that if the SME owner is not inclined towards creativity, the probability of creative manifestations will be negatively influenced despite structures and processes that actually enhance creativity. 
Table 2 Probability of creative manifestations predicted by logic model

\begin{tabular}{|c|c|c|c|c|c|}
\hline Indicator & Phase 1 & Phase 2 & Phase 3 & Phase 4 & Phase 5 \\
\hline \multicolumn{6}{|l|}{ Locus of control (LOK): } \\
\hline External $(0)$ & 0.44 & - & 0.65 & 0.04 & 0.03 \\
\hline (I) & 0.47 & - & 0.73 & 0.05 & 0.04 \\
\hline$(2)$ & 0.59 & - & 0.77 & 0.07 & 0.05 \\
\hline (3) & 0.48 & - & 0.69 & 0.04 & 0.03 \\
\hline (4) & 0.66 & - & 0.84 & 0.09 & 0.07 \\
\hline Internal (5) & 0.71 & - & 0.88 & 0.12 & 0.10 \\
\hline \multicolumn{6}{|l|}{ Business structures (OS) } \\
\hline One entrepreneurial reason (1) & - & - & - & 0.14 & 013 \\
\hline Two entrepreneurial reasons (2) & - & - & - & 0.13 & 0.12 \\
\hline Three entrepreneurial reasons (3) & - & - & - & 0.15 & 0.15 \\
\hline \multicolumn{6}{|l|}{ Value system and motivation (WN) } \\
\hline One entrepreneurial reason (1) & - & - & - & 0.03 & 0.02 \\
\hline Two entrepreneurial reasons (2) & - & - & - & 0.04 & 0.03 \\
\hline Three entrepreneurial reasons (3) & - & - & - & 0.00 & 0.00 \\
\hline \multicolumn{6}{|l|}{ Creative systems (KS) } \\
\hline Only one creative system (1) & - & - & - & 0.02 & 0.02 \\
\hline Two creative systems ( 2 ) & - & - & - & 0.06 & 0.05 \\
\hline Three creative systems ( 3 ) & - & - & - & 0.04 & 0.03 \\
\hline Four creative systems (4) & - & - & - & 0.07 & 0.05 \\
\hline Five creative systems (5) & - & - & - & 0.07 & 0.04 \\
\hline Six creative systems (6) & - & - & - & 0.09 & 0.07 \\
\hline \multicolumn{6}{|l|}{ Training (OPL) in: } \\
\hline One functional area (I) & - & - & - & - & 0.02 \\
\hline Two functional areas (2) & - & - & - & - & 0.01 \\
\hline Three functional areas (3) & - & - & - & - & 0.02 \\
\hline Four functional areas (4) & - & - & - & - & 0.08 \\
\hline Financial management training (TBI) & 0.39 & - & 0.64 & 0.04 & - \\
\hline Marketing management training (TB2) & 0.38 & - & - & - & - \\
\hline Analyses (DD9) & - & 0.65 & 0.29 & - & - \\
\hline Idea-generating sessions* (DD7) & - & 0.66 & 0.33 & - & - \\
\hline
\end{tabular}

Table 3 Comparison of indicators with descriptive statistics

\begin{tabular}{lcc}
\hline Indicator & No deficiency & Deficiency \\
\hline A. Characteristics of owner & - & \\
- Financial management training & - & - \\
- Marketing management training & - & \\
- Locus of control & - & $*$ \\
- Training in four areas & - & $*$ \\
- Value system and motivation & - \\
- Experience in four areas & $*$ \\
- Holistic approach & - \\
B. Characteristics of enterprise & - \\
- Analyses & $*$ \\
- Idea-generating sessions & - \\
- Creative systems & - \\
- Structures of enterprise
\end{tabular}

This is supported by Donckels (1992: 28), Rothwell \& Zegveld (1982: 45) and Giaoutzi, Nijkamp \& Storey (1988: 74), who agree that the SME owner is the central controlling factor in the creativity process in SMEs.

It can therefore be deduced from above arguments that creativity is not that common in the South African SMEs, and that a major contributing factor is the existing profile of SME owners. However, creativity cannot be stimulated overnight and by means of recipes. The indicators clearly outlined that skill and behavioral issues are important. The stimulation of creativity therefore cannot only be done by means of training programmes. An external environment that supports and stimulates creativity must also be created and maintained.

\section{Note}

1. It was specified in advance that no indicator would be used in the model if the p-value (the probability of excess or probability of a type I error) was larger than 0.15 . No 
indicator which had already been used in the model and had acquired a p-value of less than 0.10 in the subsequent steps, could be removed from the model.

\section{References}

Amit. R., Glosten, L. \& Muller, E. 1993. Challenges to theory development in entrepreneurship research, Journal of Management Studies, 30 (5): 815-834.

Andrén, L. \& Uudelepp. U. 1993. Search for an entrepreneurial education. Paper delivered: Internationalizing Entrepreneurship Education and Training 1993, Vienna, July 5-7.

Banfe, C. 1991. Entrepreneur - from zero to hero. New York: Van Nostrand Reinhold, 206p.

Baron, E. 1969. Creative person and creative process. New York: Holt and Rinehart, 212p

Berenson, M.L., Levine, D.M. \& Goldstein, M. 1983. Intermediate statistical methods and applications. A computer package approach. Englewood Cliffs: Prentice Hall, 579p.

Bhide, A. 1994. How entrepreneurs craft, Harvard Business Review, March-April: 150-161.

Buzan, T. 1977. Make the most of your mind. London: Penn Books, $191 \mathrm{p}$.

Charnes, A. \& Cooper. W.W. 1984. Creative and innovative management: essays in honor of George Kozmetsky. Cambridge, Massachusetts: Ballinger Publishing Company, 268p.

Churchill, N.C. \& Lewis, V.L. 1983. The five stages of small business growth, Harvard Business Review, May-June: 30-50.

Claessens, D. 1982. Bedrijfsbeheer in KMO en management in grote ondernemingen. Een vergelijkend theoretisch onderzoek. Leuven: Katholieke Universiteit, Centrum voor Economische Studien. $195 p$.

Clay, N.\& Creigh-Tyle, S. 1994. SMEs and training: evidence from the Europian Union. Scotland: Stirling: Internationalising Enterprise Education and Training.

Coetzee, J.E. \& Visagie, J.C. 1994. SMEs in South Africa: the challenge of change, Southern African Journal for Entrepreneurship and Small Business, 7(1): 43-57.

Coetzee, J.E., Havenga, J.J.D. \& Visagie, J.C. 1993. The influence of some important environmental factors on SMEs, Southern African Journal for Entrepreneurship and Small Business, 5(1): 1-11.

Cooper, R.A. \& Weekes, A.J. 1983. Data, models and statistical analysis. Oxford: Philip Allen Publishers, 400p.

Couger, J.D., Higgins, L.F. \& McIntyre, S.C. 1993. (Un)Structured creativity in information systems organizations, MIS Quarterly, 17(4): 375-391.

De Coning, T.J. 1988. 'n Ondersoek na die moontlikheid en aanwendbaarheid van ondernemingskenmerkgebaseerde kategorisering van kleinsakelui in Weskaapland. Ongepubliseerde $\mathrm{Ph} \mathrm{D}$ proefskrif. Bellville: Universiteit van Stellenbosch, 283p.

Donckels, R. 1992. Webben weven over KMO-ers en hun omgeving. Brussel: Roularta Books, 128p.

Drucker, P.F. 1986. Innovation and entrepreneurship: practice and principles. London: Pan Books, 306p.

Dutton, D. \& Kransz. 1985. The concept of creativity in science and art. Boston: Martinus Nijhoff Publishers, 208p.

D'Amboise, G. \& Muldoney, M. 1984. Specific theory for small firms: attempts and requirements. Paper delivered at Recontres de St-Gall, Zermatt, September

Engelbrecht, M. 1993. Die verband tussen kreatiwiteit en die leerstyle van Kolb. Unpublished MA thesis. Stellenbosch: University of Stellenbosch. $111 \mathrm{p}$.
Evans, J.R. \& Russel, P. 1990. The creative manager. London: Unwin Paperbacks, $215 p$

Fletcher, W. 1988. Creative people how to manage them and maximize their creativity. London: The MIT Press, $141 \mathrm{p}$

Giaoutzi, M., Nijkamp. P. \& Storey. D.J. 1988. Small and mediumsize enterprises and regional development. Chippenham. Wiltshire, Great Britain: Anthony Powe Ltd, 314p.

Gordon, J. \& Zemke, R. 1986. Making them more creative, Training Year, 23: 30-34.

Groenewald, F.P. 1970. 'n Deurskouing van enkele aspekte van die kreatiwiteitsverskynsel. Unpublished thesis. Pretoria: University of South Africa, 209p.

Guilford, J.P. 1986. Creative talents: their nature, uses and development. New York: Bearly Limited. 139p.

Gundry, L.K., Kickul, J.R. \& Prather, C.W. 1994. Building the creative organization, Organizational Dynamics: A Quarterly Review of Organizational Behaviour for Professional Managers, Spring: 22-37.

Hartman, E.A., Tower, C.B. \& Sebona. T.C. 1994. Information sources and their relationship to organizational innovation in small business, Journal of Small Business Management, 32 (1): 36-47.

Henry, J. 1991. Creative management. London: Sage Publications. $323 \mathrm{p}$.

Horvath, J. 1991. Small and medium scale manufacturing in Mexican development, 1954-1989. New York: Garland Publishing. Inc, $120 \mathrm{p}$

Johannisson, B. 1992. Entrepreneurs as learners - beyond education and training. Paper delivered at Internationalizing Entrepreneurship Education and Training 1992. Dortmund, June 23-26.

Joubert, S.J. 1993. Kreatief-begaafde studente se belewing van universiteitskultuur - 'n dubbelgevalstudie. Unpublished D Ed study project. Johannesburg: Rand Afrikaans University. 221 p.

Kreitner, R. 1989. Management. 4th ed. Arizona State University, Boston: Houghton Mifflin Company, 652p

Kuratko, D.F. \& Hodgetts, R.M. 1995. Entrepreneurship: a contemporary approach. 3rd ed. New York: The Dryden Press, 748p

Longenecker, J.G., Moore, C.W. \& Petty, S.W. 1994. Small business management: an entrepreneurial emphasis. Ohio: South Western Publishing Co, 825p.

Lytton, H. 1971. Creativity and education. London: Routledge and Kegan Paul, 133p.

Maas, G.J.P. 1996. Kreatiwiteit in Suid-Afrikaanse klein- en mediumgroot ondernemings. Unpublished Ph D study project. Bellville: University of Stellenbosch. 262p.

Morris, M. 1993. Environmental change, entrepreneurship and competitive change: implications for large and small South African firms, Business Alert, 143: 1-16.

National strategy for the development and promotion of small business in South Africa. 1995. White Paper of the Department of Trade and Industry, February, 58p.

Pleitner, H.J. 1984. The entrepreneur - centre of the management in small and medium-sized firms. Paper delivered at Recontres de StGall, Zermat, September.

Roos, H., Bos, W., Donckels, R., Lelgemann, G. \& Witterwulghe, R 1986. Small and medium-sized enterprises. Keystone for a free and prosperous Europe. Netherlands: Tilburg University Press. 219p.

Rothwell, R. \& Zegveld, W. 1982. Innovation and the small and medium sized firm - their role in employment and in economic change. London: Franes Printer, 268p.

Scholhammer, H. \& Kuriloff, A.H. 1979. Entrepreneurship and small business management. New York: John Wiley and Sons. $608 \mathrm{p}$. 
Sexton. [).L \& Van Auken. P. 1985. A longitudinal study of small business strategic planning. Journal of Small Business Manage$m e^{\prime n t}$ i3 (1): 13-15.

Smith. V R \& Miner. J.B. 1983. Type of entrepreneur, type of firm. and managerial motivation: implications for organizational life cycle theory. Strategic Management Journal, 4: 325-340.

Smuts. H.E 1986. 'n Ondersoek na die bevordering van kreatiwiteit Ongepubliseerde D Litt et Phil-proefskrif. Pretoria: Universiteit van Suid-Afrika. 512p

Smuts. H.E. 1992. An interactional approach to creativity, South African Journal of Psychology, 22 (2): 44-51

Standard Industrial Classification of all economic activities. 1981 , January

Stemberg. R. 1988. The nature of creativity: contemporary psychological perspectives. New York: Cambridge University Press, 454p.

Thomas, W. 1995. The SMME White Paper - beginning of a new era?, Southern African Journal for Entrepreneurship and Small Business, 7 (1): 12-28

Visagie. J.C. 1996. SMMEs social responsibility in a changing South Africa - beginning of a new era? Southern African Journal for Entrepreneurship and Small Business, 8 (1): 35-47.

Welsh. G.S. 1975. Creativity and intelligence: a personality approach. University of North Carolina at Chapel Hill: Institute for Research in Social Science. 295p

West, M. \& Farr, J.L. 1990. Innovation and creativity at work in psychological and organizational strategies. New York: John Wiley and Sons, 349p.

\section{Annexure A}

Variables for logistic regression and log-linear model construction

\begin{tabular}{|c|c|c|c|}
\hline A. Characteristics of entrepreneur (single) & Compound & $\begin{array}{l}\text { Number of } \\
\text { questions }\end{array}$ & $\begin{array}{l}\text { Scale } \\
\text { type }\end{array}$ \\
\hline Locus of control (LOK) & Locus of control (LOK) & 6 & 7 \\
\hline \multicolumn{4}{|l|}{ Training: financial management (TB1) } \\
\hline \multicolumn{4}{|l|}{ Training: marketing management (TB2) } \\
\hline Training: human resources management (TB3) & Training in four areas (OPL) & 4 & 5 \\
\hline \multicolumn{4}{|l|}{ Iraining: general management (TB4) } \\
\hline \multicolumn{4}{|l|}{ Experience: tinancial management (TC1) } \\
\hline \multicolumn{4}{|l|}{ Experience: marketing management (TC2) } \\
\hline Experience: human resources management (TC3) & Experience in four areas (ERV) & 4 & 5 \\
\hline \multicolumn{4}{|l|}{ Experience: general management (TC4) } \\
\hline Technical skills (TD1) & Technical skills (TD1) & 1 & 2 \\
\hline \multicolumn{4}{|l|}{ Need to arrange own work (TE1) } \\
\hline \multicolumn{4}{|l|}{$\begin{array}{l}\text { Fssential contribution towards economic growth and development } \\
\text { (TE2) }\end{array}$} \\
\hline To prove to others and to myself that I can be successful (TE3) & $\begin{array}{l}\text { Value system and motivation } \\
\text { (WN) }\end{array}$ & 6 & 4 \\
\hline \multicolumn{4}{|l|}{ To ensure a good standard of living for me and my family (TE4) } \\
\hline \multicolumn{4}{|l|}{ To generate and to develop unique ideas (TE5) } \\
\hline \multicolumn{4}{|l|}{ To improve my financial income (TE6) } \\
\hline Taking of risks (THI) & Taking of risks (TH1) & 4 & 1 \\
\hline \multicolumn{4}{|l|}{ Maintaining a high gross profit margin (TII) } \\
\hline \multicolumn{4}{|l|}{ To stay informed of social and economic tendencies (TI2) } \\
\hline \multicolumn{4}{|l|}{ Careful maintenance of the quality of products/services (TI3) } \\
\hline Participation in organised trade activities in the community (TI4) & Holistic approach (G) & 6 & 4 \\
\hline \multicolumn{4}{|l|}{ Careful checking of running costs (TIS) } \\
\hline \multicolumn{4}{|l|}{ To be informed of activities of competitors (T16) } \\
\hline \multicolumn{4}{|l|}{ B. Business features (single) } \\
\hline \multicolumn{4}{|l|}{ Open communication (DA2) } \\
\hline \multicolumn{4}{|l|}{ Heterogeneous staff policy (DA4) } \\
\hline \multicolumn{4}{|l|}{ Experimenting (DA6) } \\
\hline Informed of long-term plan (DA8) & Business structures (OS) & 7 & 4 \\
\hline
\end{tabular}

Training is an integral part (DA10)

Relevant system of acknowledgement (DA12)

Relevant policy and procedure (DA14) 
Variables for logistic regression and log-linear model construction

\begin{tabular}{lll}
\hline View of environment (OO) & View of environment (OO) & 4 \\
Proposal schemes (DD1) & & \\
Project teams (DD3) & Creative systems (KS) & \\
Discussion groups (DD5) & & 7 \\
Idea-generating sessions (DD7) & \\
Analysis (DD9) & \\
Debates (DD11) & \\
\hline C. Dependent variable & \\
\hline Binary classification (V43) & \\
- No creativity $=0$ & \\
- Creative $=1$
\end{tabular}

\section{Humboldt/South African Research Award for 2000}

Nominations are invited for the Humboldt/South African Research Award to international renowned German scholars in the fields of the sciences (natural and social), humanities, medicine, engineering and argriculture in recognition of their achievements in research, for promoting research cooperation between South Africa and Germany and contributing to research capacity building in South Africa. Only full or associate professors. or scholars of equivalent standing outside universities may be nominated for this research award. The nominee's academic achievements must be internationally recognised through, for example, proven success in resaerch work. positive responses by peers to the nominee's published work and by other previous distinctions.

Nominations must be made by leading researchers in South Africa. The nominating South African scholar is required to quarantee that sufficient material and equipment are available for the research work envisaged by the award winner during his/her stay in South Africa or that, particularly in the case of studies in the humanities, access to archives or libraries is assured.

Nominations can be submitted to the NRF, P.O. Box 2600, Pretoria, 0001 (Attention: Mrs R. Robertson) at any time of the year. Those received by 31 October of every year will be processed and considered at the meeting of the Humboldt/South African Research Awards' Panel during February/March of every year. Those received after the above date will stand over to the next year for processing.

Enquiries may be directed to Mrs R. Robertson, telephone number (012) 481-4102, telefax (012) 349-1179, e-mail rose@nrf.ac.za. 